\title{
践 New Disease Reports \\ First report on a variant of Squash leaf curl China virus (SLCCNV) infecting Benincasa hispida in India
}

\author{
S.U. Mohammed Riyaz, S. Deepan, G. Dharanivasan, M.I. Jesse, Raja Muthuramalingam and K. Kathiravan*
}

Department of Biotechnology, University of Madras, Guindy Campus, Chennai-600 025

*E-mail: drkkathiravan@gmail.com

Received: 06 Sep 2013. Published: 30 Dec 2013. Keywords: Begomovirus, viral plant disease

Benincasa hispida (family Cucurbitaceae), known as winter melon, white gourd, winter gourd or ash gourd, is one of the commercially most important vegetable crops cultivated in the Indian subcontinent. Leaf curl disease of winter melon has become a serious problem in the state of Tamil $\mathrm{Nadu}$, which is one of the major growing areas for this crop in India. Severe disease incidence is found in the Perambalur district state of Tamil Nadu, with up to $100 \%$ crop loss recorded over the period December 2012 to May 2013. Infected plant leaves exhibited typical symptoms of upward leaf curling, crinkling, puckering, yellowing and reduced leaf blade area (Fig. 1). The bipartite Squash leaf curl China virus-India (SLCCNV-IN) (Muniyappa et al., 2003; Singh et al., 2009), genus Begomovirus in the family Geminiviridae, is one of the major disease-causing factors severely affecting winter melon in India. Total DNA used as template for PCR was isolated from symptom-bearing and symptomless leaf samples using the Dellaporta method. A 771 bp fragment of a begomoviral DNA-A component was amplified using coat protein gene-specific degenerate primers designed for this study (FP: 5'-ATGTCSAAGCGWCCRGCAGA-3, 5'-ATTCTTMACAGTWGCAGTGC-3').

Rolling circle amplification (RCA) was performed using an Illustra Templiphi 100 Amplification Kit (GE Healthcare Limited, UK) according to the manufacturer's protocol and digested with BamHI. A resulting 2.7 $\mathrm{kb}$ fragment was purified via gel electrophoresis and cloned into BamHI linearised pBluescript II KS (+) (Fig. 2). No such DNA band was observed for symptomless plant samples treated in parallel. The cloned fragment represented full-length viral DNA-A as identified by sequencing to reveal 2,739 bases with 8 ORFs (AV1, AV2, AV3, AC1, AC2, AC3, AC4, AC5 according to the designation of Padidam et al., 1995) (GenBank Accession No. KF188433). BLASTn was performed for the viral genomic sequence (KF188433) against the non-redundant/nucleotide (nr/nt) databases, showing 98\% and 91-96\% nucleotide sequence identity with DNA-A components of Squash leaf curl China virus-India [India:Coimbatore:Pumpkin] (AY184487) (Brown et al., 2012) and other Cucurbitaceae-infecting Squash leaf curl China virus-India isolates (EU573715, DQ026296, GU967381, AM286794, JN587811, KC857509, AF509743, AB330078, AM260205, KC171648, HM566112, AM260206, AF509741, AB027465, EF197940, EU543562, EU487031), respectively. According to Brown et al. (2012), we report that the Begomovirus causing high losses of Benincasa hispida in India is a variant of SLCCNV-IN [IN:Coi:Pum] and has been named Squash leaf curl China virus - India isolate KP1 according to its segment DNA-A.

A phylogenetic tree (Fig. 3) was calculated by the neighbour-joining method with MEGA version 5.2. (Tamura et al., 2011). The variant SLCCNV-IN (KF188433) is supported by a bootstrap value of $100 \%$ and is grouped within the SLCCNV-IN [IN:Coi:Pum] isolates from Coimbatore in cluster B whereas SLCCNV-CN [TH:NP:WG:07] isolates (EU543562) from Benincasa hispida in Thailand (Sawangjit, 2009) were found to be grouped in a separate cluster A. We thus found that the Begomovirus SLCCNV-IN KP1 infection in Benincasa hispida (KF188433) in India is divergent from that in Thailand. This report describes the existence of SLCCNV-IN infection in Benincasa hispida in India for the first time.

\section{Acknowledgements}

The authors thank University Grant Commission (UGC), Government of India for financial assistance. S.U.M. thanks UGC-NRCBS, Madurai Kamaraj University, Madurai, Tamil Nadu, India for providing training. Special thanks to Dr. Amit Gal-on, ARO, Bet Dagan, Israel for valuable suggestions and ideas.

\section{References}

Brown JK, Fauquet CM, Briddon RW, Zerbini M, Moriones E, NavasCastillo J, 2012. Geminiviridae. In: King AMQ, Adams MJ, Carstens EB, Lefkowitz EJ, editors. Virus Taxonomy - Ninth Report of the International Committee on Taxonomy of Viruses. London, UK: Associated Press, Elsevier Inc., pp. 351-373.

Muniyappa V, Maruthi MN, Babiha CR, Colvin J, Briddon RW, Rangaswamy KT, 2003. Characterisation of pumpkin yellow vein mosaic virus from India. Annals of Applied Biology 142, 323-331. http://dx.doi.org/10.1111/j.1744-7348.2003.tb00257.x

Padidam M, Beachy RN, Fauquet CM, 1995. Tomato leaf curl geminivirus from India has a bipartite genome and coat protein is not essential for infectivity. Journal of General Virology 76, 25-35. http://dx.doi.org/10.1099/0022-1317-76-1-25Singh AK, Mishra KK. Chattopadhyay B, Chakraborty S, 2009. Biological and molecular characteriz

Sawangjit S, 2009. The complete nucleotide sequence of Squash leaf curl China virus-[Wax gourd] and its phylogenetic relationship to other geminiviruses. Science Asia 35, 131-136.

http://dx.doi.org/10.2306/scienceasia1513-1874.2009.35.131Singh AK. Mishra KK. Chattopadhyay B, Chakraborty S, 2009. Biological and molecu Singh AK, Mishra KK, Chattopadhyay B, Chakraborty S, 2009. Biological and molecular characterization of a begomovirus associated with yellow mosaic vein mosaic disease of pumpkin from Northern India. Virus Genes 39, 359-370. http://dx.doi.org/10.1007/s11262-009-0396-4

Tamura K, Peterson D, Peterson N, Stecher G, Nei M, Kumar S, 2011. MEGA5: Molecular evolutionary genetics analysis using maximum likelihood, evolutionary distance, and maximum parsimony methods. Molecular Biology and Evolution 28, 2731-2739.

http://dx.doi.org/10.1093/molbev/msr121

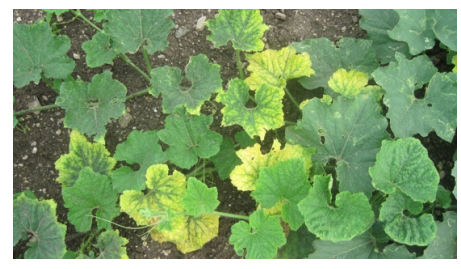

Figure 1

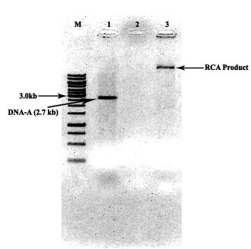

Figure 2

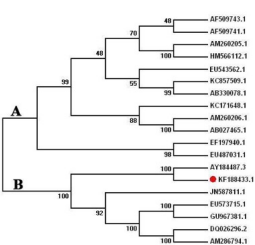

Figure 3

To cite this report: Mohammed Riyaz SU, Deepan S, Dharanivasan G, Jesse MI, Muthuramalingam R, Kathiravan K, 2013. First report on a variant of Squash leaf curl China virus (SLCCNV) infecting Benincasa hispida in India. New Disease Reports 28, 20. http://dx.doi.org/10.5197/j.2044-0588.2013.028.020 